\begin{tabular}{|c|c|c|c|c|c|c|}
\hline \multirow{4}{*}{ Impact Factor: } & ISRA (India) & $=3.117$ & SIS (USA) & $=0.912$ & ICV (Poland) & $=6.630$ \\
\hline & ISI (Dubai, UAE & $=0.829$ & РИНЦ (Russia & $=0.156$ & PIF (India) & $=1.940$ \\
\hline & GIF (Australia) & $=0.564$ & ESJI (KZ) & $=8.716$ & IBI (India) & $=4.260$ \\
\hline & JIF & $=1.500$ & SJIF (Morocco & $=\mathbf{5 . 6 6 7}$ & OAJI (USA) & $=0.350$ \\
\hline
\end{tabular}

\section{SOI: 1.1/TAS DOI: 10.15863/TAS International Scientific Journal Theoretical \& Applied Science}

p-ISSN: 2308-4944 (print) e-ISSN: 2409-0085 (online)

Year: 2019 Issue: $03 \quad$ Volume: 71

Published: $30.03 .2019 \quad$ http://T-Science.org
QR - Issue

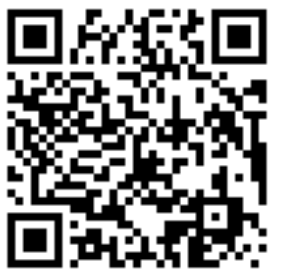

Zovqiddin Norqulovich Suvanov

Alisher Navoi Tashkent State University of the Uzbek Language and Literature $(\mathrm{PhD})$ post-graduate student suvonovz@inbox.ru

\title{
THE ROLE OF LITERARY-AESTHETIC LOOK OF THE AUTHOR IN THE ANALYSIS OF THE WORK ON THE EXAMPLE OF THE NOVEL "IT CAN NOT DIE IN THE WORLD."
}

Abstract: In the article, it is stated that one of the factors that influenced the writer to write his works was a radical change in society. In this regard, it seems that the heroine of the work reflects the artistic purpose of the author. The article focuses on some of the distinctions and differences in the world of heroes. In the analysis of the novel, he tried to find a solution to the problem of the nature of the heroes and the literary-aesthetic views of the author. In the study, the findings of the research on the novel have helped make clear conclusions in the analysis.

Key words: society, art, image, aesthetic look, intuition, satire, author, character.

Language: English

Citation: Suvanov, Z. N. (2019). The role of literary-aesthetic look of the author in the analysis of the work on the example of the novel "It can not die in the world". ISJ Theoretical \& Applied Science, 03 (71), 481-484.

Soi: http://s-o-i.org/1.1/TAS-03-71-44 Doi: crossef https://dx.doi.org/10.15863/TAS.2019.03.71.44

\section{Introduction.}

In recent years, especially in the social networks, there has been a lot of commentary on the personality of Tog'ay Murad and his educational content. His fans, with their active participation on TV, radio, and the media, are often trying to make people aware of the treasury of meaning in new books by the author. The novel "One cannot die in this world" is also being researched by some scholars and reviewed by fans; it also brings excitement to the heart of its readers. The idea of the novel is significant with its internal logical integrity and socio-historical significance. The main characters in it are distinguished probably as a result of the significant artistic aesthetic value. Even some episodes in the story that seem to be unbelievable, do not seem faulty to the readers of the book. Because our ancestors have read and heard folk stories and various eposes about wars. Therefore, in the genesis of our people, there is the ability to understand the artistic reality or the central plot among unbelievable scenes.

The reader faces the problem of a deeper understanding the writer's work. Readers are required to approach the novel taking into account the writer's spiritual and social world view from the idea the author is suggesting. It is important to know the concept of creators to know more about the logics in the character of the heroes. It is necessary to take into account such factors as the historical conditions in which this plot is set, the socio-political situation in which the writer lives, the ideological environment, the literary process, and the writer's style.

The sharp eyesight, profound creative heritage and noble intentions of the honest writer who knew the city life and the lives of the people, whose heart was linked to the hearts of those martyred people, and who was genuinely sympathetic to them, can be felt in the interpretation of each event in the story, appearance of the heroes, their manner of speaking and inner feelings. In addition, the novel makes us think about these aspects.

No matter how strong is the will to create a genuine piece of art, mere talent or noble intentions and skillfulness are not enough. To achieve this one must also have enough feelings and haughtiness. To this regard, Tog'ay Murod stated "It's the power of my intuition thanks to which I see the attractiveness of life that no writer can see, and I can hear the tunes of life that no writer can hear, and I can write the stories that no writer can even dream about.. The tragic aspect of my intuition is that sitting at home I can know what is happening in the world. I feel it and experience that event myself That's what is bad! As a resultl, I suffer psychological distress. I wonder why the world is so. I am so worried about that. I want to leave this world. So, for people of my category it's hard to live! "[1]. Perhaps, in order to create a true artistic piece of work, 


\begin{tabular}{|c|c|c|c|c|c|c|}
\hline \multirow{4}{*}{ Impact Factor: } & ISRA (India) & $=3.117$ & SIS (USA) & $=0.912$ & ICV (Poland) & $=6.630$ \\
\hline & ISI (Dubai, UAE & $=0.829$ & РИНЦ (Russia & $=0.156$ & PIF (India) & $=1.940$ \\
\hline & GIF (Australia) & $=0.564$ & ESJI (KZ) & $=8.716$ & IBI (India) & $=4.260$ \\
\hline & JIF & $=1.500$ & SJIF (Morocco & $=5.667$ & OAJI (USA) & $=0.350$ \\
\hline
\end{tabular}

first of all, it is necessary to understand the life and the behavior of thousands of people, to live side by side with those diverse people who have their own outlook on life. This can be proved by the substantial creative life and classical books of hundreds of well-known writers who regarded this truth as the greatest school for themselves, and who took lessons and inspiration from it. So, we can now say with confidence that we have become fully aware of the fact that Tog'ay Murod, who reached the peak of his artistic career and has always enjoyed the life and great spirituality of the people, considered the life to be a source of creativity.

According to the creative method, the images can be romantic and realistic. Examples of realistic characters can be found among the heroes of this book. The worldview of realistic characters fits in with that of real people in real life. Even though the writer's fantasy is always added to it, the author cannot avoid the accuracy in depicting the images. Examples can be such heroes as Botir, Rajabov, Mirzaev, Madiyev, Sharof Rashidov, Obod, Dilbar.

According to literary types and genres, styles, and visual aids, images fall into specific groups. In satiric imagery, laughter and criticizing the defects in personality dominate. The internal ugly worlds of heroes that are invisible but which we can feel subconsciously are exposed. "He put his hands on his back. He stuck out the stomach which he had not. Trying to do that he bent back. The stomach that he did not have was in his front, and his back disappeared inside. And he himself was bending back [2, 206]. These kinds of mimics and gesture of Botir cause the laughter of a reader.

The biography of the author, called "I", is a valuable and trustworthy source in this regard. Hence, the secret of authenticity and genuineness of events in the novellas of the writer and in this particular novel, reality and simplicity of the expressive means must be first of explained by the sincerity of his confession, his versatile creativity, exemplary life style. In short, the explanation must be searched in the rich and unique personality. The writer writes: "But ... fifteen years ago, the Uzbek literature and art ... lived through the era of stereotypes, and lived through a self-mutilated period. It was the period of pride, frivolity, and arrogance. Uzbek literature and art remained in the midst of the agony. The writers who created Uzbek culture were restricted. The writers, who enriched the Uzbek literature, were moved aside. Representatives of the great legacy of writers and artists were ignored. Those were the group of people wearing the mask of reconstruction. Flocks of people wearing the mask of democrats. Traitors wearing the masks of patriots. Gangsters wearing the masks of honest men. I described this period in details in my novel "One cannot die in this world" [3]. Dilbar, a heroine from the novel, considers Madiyev to be the leader of the gangsters wearing the mask of democrats. Later she was proved to be right. We will not be wrong if we say that such personages of the novel as Botir qushchi and Rajabov are representatives of real Uzbek intelligentsia of that period. They do not turn into different people. In the process of reading, we can observe the dynamics of these heroes. They develop gradually.

The writer who understands psychology of readers while delivering psychic state of the hero without losing his track as he understands subconscious reality deeply and skillfully demonstrates this to the reader. Umarali Normatov, a scientist who understands the state of the hero in this regard, is convinced. "Although Botir is a real communist his nature, humanistic, national, universal, and Muslim feelings were also rooted deep in his heart. When their time came, they demonstrated themselves by making him do the good deeds which were against the beliefs he had in that awful time. This precious feeling served as the only key to open the door out of psychological tortures he was experiencing" [4, 225]. Even though the views of the writer and the hero were consistent, people of the transition period notice the evolution in the world of imagination, and the blasphemous people. The poet Chulpon described it as follows: "Imagination, imagination... Only imagination is beautiful. I fear to look into the eyes of truth". It is not easy to create the portrait of the people who lived in such period,

Since the time of the creation of the human race, they have been trying to explain the phenomena of life with the human mind. But all the events in folklore seem to be solved. Each of us has been crafted by our ancestors with knowledge. The phrase "your deeds will haunt you" means that we have to be responsible for everything we do. The same was mentioned in the folk prose in the case of Togay Murad's hero, First Secretary of the Regional Party Committee Rajabov. The only fact that journalist Madiev went on business trip and called Rajabov led to his arrest. When Batir party member went to the hospital to get him out (Rajabov himself told him to do it). "If you follow the doctrine of the party, you will not be in trouble. It is between us two, let's get Madiyev out of here. Just let no one know ... - That's Rajabov's report. Here is his personal signature. He signed it himself "[2, 239]. We have no choice but to feel sorry for the staff who worked at that time. Under those circumstances, managers have been accustomed to bureaucracy, even though they did not want to. Although he did this unwillingly, he himself would eventually suffer in this madhouse. It is difficult to say that he suffered from this as a revenge for the wrong he did to Madiyev. Because at that time, the things that Madiev did (calling to the governor) were considered to be the acts that would destroy the reputation of the post and post holder.

The complex of images - system of images in a fiction book (Ketmon from "Fields of my father"Aqrab-Dehqonqul-Qulmat, and etc.) Qodirqul, 


\begin{tabular}{|c|c|c|c|c|c|c|}
\hline \multirow{4}{*}{ Impact Factor: } & ISRA (India) & $=3.117$ & SIS (USA) & $=0.912$ & ICV (Poland) & $=6.630$ \\
\hline & ISI (Dubai, UAE & $=0.829$ & РИНЦ (Russia & $=0.156$ & PIF (India) & $=1.940$ \\
\hline & GIF (Australia) & $=0.564$ & ESJI (KZ) & $=8.716$ & IBI (India) & $=4.260$ \\
\hline & JIF & $=1.500$ & SJIF (Morocco & $=5.667$ & OAJI (USA) & $=0.350$ \\
\hline
\end{tabular}

Kholmat malay, Eson xizmatkor, Botir qushchi, Zaynab Momo, Obod Mirzakhujayeva, and Dilbar "No one can die in this world" - are described systematically with their family roots so systematically, that the author directly refers to such question always asked in Uzbek culture as: Who are his ancestors? or What is their current social status? If we turn to the dialogue between Botir Firqa and Zaynab khatun:

“- Are you the youngest wife of Mirzakho ‘jaboy Zaynab...Zaynab khatun?

- Yes, you are right.

- What is your daughter's name?

- Obod.

- Obod, Obod... in other words, she is Mirzakho'jaboy's daughter?

- Yes, right. She is our daughter!

- Do you realize whose daughter you are taking to the bazaar? Her father is not just a man. Her father is Mirzakho'jaboy!

The mother did not say a word. She was dead silent.

Mirzakho“jaboy’s daughter?! - said Botir firqa. - It is true, that Mirzakho'jaboy did not like the soviet government and ran away to Afghanistan. But he is the elder son of Saidkho " ja eshon. In other words she is eshonzoda (child of eshon)" [2, 211]! Botir's attention to the origin and family of the girl draws our attention to this extract. Reading it we can realize that even though he was living in the soviet period, he still has not lost the feeling of the respect to eshons and readiness to serve them which was a tradition in his family.

Time has brought Mirzakhodzabay's children up as true Soviet people. In the plot, the author pays special attention to the fact that Mirzakhodzabay's daughter became publicly known. The nature of Zainab, the mother, who admires and dreams of a television presenter and Obod, the daughter, has changed dramatically, which does not necessarily mean that one presupposes the other. Obviously, Obod whose vail was removed by the wind of changes or, whose face had never seen a vail could never become a daughter warming her mother's heart to Zaynab momo. It was not her mother Zaynab who educated her. It was the soviet ideology which was implanted into the minds of school learners.

In the book, the above process is vividly depicted in the spirit of time. The main purpose of the author was not to create a brighter picture of the nature of Zaynab and Obod's life, but to show a more vivid picture of the nature of such people as Dilbar (Dilya) and others. The author's purpose was to attempt to revive the reality in the consciousness of school children in soviet period and to illustrate the changes and consequences of the perestroika period so the reader could imagine them.
Everything that Dilya did when she was a teenager and the fact that she has easily turned into a muslim woman irritated Botir firqa. "- Where have been so far? Who have you been so far?

Botir firqa put his hands on his hips and pondered...

"This young woman sat on the laps of so many men, - thought Botir firqa. - She spent her time with so many men." [2.260]. The hero is saddened by the divergence in Dilya's words and deeds. The reader sees the events as a matter of Botir's perception. If the thoughts of Dilbar were discussed, then the reader would have seen the true reality. Is Dilbar true in her regrets or is she hypocritical? These ideas will remain open in the book. But the reader automatically relies on Botir's opinion and has a negative impression of Dilbar. Unfortunately, Botir is a leading figure in the novel. Whether we want or not, the events follow the footsteps of the main character. The views of the personages other than main characters are not taken into account.

According to the main idea of the book, instead of hoping for a better life in the other world, the heroes believe they the laws of life and new conditions will improve. The people's leaders will support the idea of moving from twiddling to active work. Looking at the logic of the heroic characters, the boundary between life and death for the literary hero passes through national coloring. "This is not a coincidence. Because, according to pragmatic aesthetics of modernism, the ultimate aim of any activity is human beings and possibility fot them to achieve the most radiant experiences in their material life. The practical experience of such a subject should be based on moral, religious, and aesthetic values. In our opinion, the hero of the novel moves towards internal affiliation and spiritual integrity. The subject combines social and naturalism into a single act. Therefore Botir can not die and die without performing his good deeds or handing over his fidelity to the faithful hands "[5]. 40]. Indeed, according to the author 's aesthetic ideals, Botir is characterized by the essence of human nature. It is understood that this aesthetic does not have any basis for looking at the particular characteristic of Sufism.

As Botir is not an image of a person with inborn leadership talent, but a pure practitioner. He was promoted by that community, and through this position he gained a position in the political life of society. It place a symbolic meaning upon the episode of removal of the plane trees through the hashar of the end of the work. He describes the hero's psychological state at the time as a person who "wakes up from daytime sleep" through psychological parallels. The hero believes that the use of his exploitation in the removing trees when he was quite old ( around 90) was a kind of assistance to perestroika representatives in destroying the society he had been building for thirty years. And he suffered emotionally from these 


\begin{tabular}{|c|c|c|c|c|c|c|}
\hline \multirow{4}{*}{ Impact Factor: } & ISRA (India) & $=3.117$ & SIS (USA) & $=0.912$ & ICV (Poland) & $=6.630$ \\
\hline & ISI (Dubai, UAE & $=0.829$ & РИНЦ (Russia & $=0.156$ & PIF (India) & $=1.940$ \\
\hline & GIF (Australia) & $=0.564$ & ESJI (KZ) & $=8.716$ & IBI (India) & $=4.260$ \\
\hline & JIF & $=1.500$ & SJIF (Morocco & $=5.667$ & OAJI (USA) & $=0.350$ \\
\hline
\end{tabular}

events. The spirit of the novel motivates creativity, the desire to establish the material worldis strong. Hero is reborn as a man of moral, religious, divine and aesthetic values. To understand and explain poetics of the novel, the above points should be considered. The published opinions reflect the existence of many individual aspects of literary criticism.

\section{Conclusion}

One of the factors that influenced the writer to write his works was the transformation in society. In this regard, we can see how the writer's artistic purpose reflects the heroes of the work. At the end of the story, attention is drawn to some of the distinctions and differences in the views of Botir, Rajabov, Madiev and Dilbar. The author is trying to uncover the social and political environment of that time, through people devoted to soviet ideology and young people with the ideas of "new" thinking and the re-structuring mindset.

It is a good idea to look at the description as the key to the description of the two genealogies in the novel (Botir, Dilbar) and to link it with this analysis. We have tried to find a solution to the problem of the nature of the heroes and the artistic work that he has played on the basis of literary-aesthetic views of the author. Indeed, in the play, it was seen that there were complex images that would reveal the grief of Tog'ay Murad. Through the record of the author's work on the novel, we have been able to make clear conclusions in the analysis during the research.

\section{References:}

1. Tog'ay, M. (2003). Reviewing books we read can open eyes. Yoshlik, № 5-6.

2. Tog'ay, M. (2018). Selected works. (p.206). Tashkent: Sharq.

3. Tog'ay, M. (2003, April 26). Reviewing books we read can open eyes. Ma'rifat.

4. Normatov, U. (2010). Talks about arts: critical reviews of books, essays, memoirs, and etc. A rare monument or the finale of the series of books. (p.225). Taskent: Muharrir.

5. Yakubov, I. (2018). Poetics of the novels written during Independence period. DSc dissertation, (p.40).
6. Hamraev, K. (2018). Compositions poetry in the modern Uzbek story. PhD diss. (p.19).

7. Umida, R. (2017). The promises are from the rays of the olive. Marriage. June 14. On page 47.11

8. Koshzhonov, M. (1980). Theoretical Figures. (p.182). Tashkent: Fan.

9. Hotamov, N., \& Sarimsoqov, B. (1983). Russian-Karakalpak Dictionary of Literature terms. (p.376). Tashkent: Teacher.

10. Mallaev, N. (1976). The history of the Uzbek literature. (p.450). Teacher. 